\title{
Editorial
}

\section{A New MDPI Proceedings Journal: Computer Sciences and Mathematics Forum}

\author{
Constanze Schelhorn (iD)
}

check for updates

Citation: Schelhorn, C. A New MDPI

Proceedings Journal: Computer

Sciences and Mathematics Forum. Comput. Sci. Math. Forum 2021, 1, 1. https://doi.org/10.3390/ cmsf2021001001

Published: 26 November 2021

Publisher's Note: MDPI stays neutral with regard to jurisdictional claims in published maps and institutional affiliations.

Copyright: (C) 2021 by the author Licensee MDPI, Basel, Switzerland. This article is an open access article distributed under the terms and conditions of the Creative Commons Attribution (CC BY) license (https:// creativecommons.org/licenses/by/ $4.0 /)$.
MDPI, Avinguda Madrid, 95, 5-3, 08011 Barcelona, Spain; constanze.schelhorn@mdpi.com; Tel.: +34-93-639-7662

Academic conferences and other scientific events are an integral part of scientific communication, serving as a platform to discuss novel findings, to establish collaborations, and to foster scholarly exchange in general. MDPI supports open academic communication in all its forms; we believe it is essential to provide an open record to the outputs of scholarly events. Therefore, in 2017, MDPI established Proceedings [1], an open-access outlet dedicated to publishing relevant discussions and results communicated at academic meetings. The positive reception of this initiative ultimately led to the launch of a series of field-specific proceeding journals (Biology and Life Sciences Forum, Chemistry Proceedings, Engineering Proceedings, Environmental Sciences Proceedings, Materials Proceedings, Medical Sciences Forum, and Physical Sciences Forum) [2].

We are proud to announce the launch of Computer Sciences and Mathematics Forum (ISSN: 2813-0324) [3], a new proceedings platform covering the expanding field of computer sciences and mathematics. As for all our proceeding journals, publications in Computer Sciences and Mathematics Forum, will bring a multitude of benefits, such as individual indexation, easy citeability of all published items via digital object identifier (DOI), a dedicated webpage for the conference and, of course, open access. We welcome all scientific event organizers interested in contributing to Computer Sciences and Mathematics Forum to contact the editorial office.

We look forward to collaborating with conference organizers and committees and providing support the computer sciences and mathematics community.

\section{References}

1. Proceedings Home Page. Available online: https://www.mdpi.com/journal/proceedings (accessed on 12 November 2021).

2. MDPI Proceedings Journals Home Page. Available online: https://www.mdpi.com/about/ proceedings (accessed on 12 November 2021).

3. Computer Sciences and Mathematics Forum Home Page. Available online: https://www.mdpi. $\mathrm{com} /$ journal/csmf (accessed on 12 November 2021). 